\title{
UBIORY LUDWIKA II LEGNICKO-BRZESKIEGO I JEGO ŻONY, ELŻBIETY Z HOHENZOLLERNÓW
}

SŁowA KLuCzowe: ubiór średniowieczny; ikonografia; Śląsk

KEYwORDs: medieval clothing; iconography; Silesia

Problem rzeczywistego wyglądu Ludwika i Elżbiety, księstwa legnicko-brzeskich, pełnił niejednokrotnie ważną rolę w identyfikacji cennego zabytku. Jest to nagrobek znajdujący się obecnie w południowej kaplicy katedry św. św. Piotra i Pawła w Legnicy (ryc. 1). Historię badań nad nim przedstawiliśmy w osobnym opracowaniu, przywołując także kilka nowych świadectw wiążących go z Ludwikiem II legnicko-brzeskim i Elżbietą z Hohenzollernów (Wasiak, Badowska 2014). Udało nam się przy tej okazji zaledwie wstępnie poruszyć kwestię wyglądu obu przedstawionych na nim postaci. Uznaliśmy za konieczne rozwinięcie tego tematu zarówno ze względu na kilka nowych spostrzeżeń kostiumologicznych, jak i dla porównania różnych wizerunków tej samej osoby utrwalonych w ikonografii średniowiecznej. Znamy, co prawda, zaledwie jeden (choć bardzo ciekawy) wizerunek księżnej Elżbiety, ale w przypadku jej pierwszego męża - Ludwika, możemy mówić już o pięciu, co jest już dość znaczną liczbą. O podobiznach Ludwika II legnicko-brzeskiego pochodzących z epoki, wspominano w różnych kontekstach (Czechowicz 2003: 128-130; Kaczmarek 1991a; 1991b; Karłowska-Kamzowa 1979: 79), jednak nigdy nie porównywano ich ze sobą, ani nie przeprowadzono próby analizy wizerunku tej malowniczej postaci silnie związanej z kulturą rycerską i dworską późnego średniowiecza. Sądzimy, iż nadszedł czas na bliższe przyjrzenie się jednemu z najpotężniejszych książąt śląskich, przyjacielowi i dworzaninowi tak znaczącej postaci jaką był Zygmunt Luksemburski, oraz jego drugiej żonie, córce elektora bran- 
denburskiego Fryderyka I. Zamierzamy teraz skupić się na zagadnieniach wizerunku tej pary, które powinny dostarczyć nowych informacji zarówno dla bliższego poznania dawnej rzeczywistości jak i weryfikacji dotychczas zebranych informacji.

W oczywisty sposób, ubiór, który rekonstruujemy w niniejszym artykule będzie charakterystyczny dla najwyższych warstw późnośredniowiecznego społeczeństwa, stykających się zarówno z uniwersalną kulturą dworską, jak i lokalną specyfiką wielu wybitnych ośrodków władzy w północnej Europie. Liczne podróże pechowego krzyżowca Ludwika II, zarówno „samodzielne” jak i odbywane $\mathrm{z}$ dworem Zygmunta Luksemburskiego, znaczące powiązania rodziny jego żony jak i zamiłowania księcia do wystawnego, pełnego przygód życia, rozbudzają pewne oczekiwania wobec próby rekonstrukcji wizerunku pary książęcej. Nie zamierzamy twierdzić, iż przedstawione w ikonografii stroje są identyczną kopią odzienia noszonego przez historyczne postaci. Jednak ze względu na jakość artystyczną i charakter przedstawień, niewątpliwie mamy do czynienia z szatami, które w czasie powstawania dzieł uważane były za stosowne dla prezentowanych osób. $Z$ bardzo dużym prawdopodobieństwem można też przyjąć, iż ukazany wizerunek nosi cechy ubioru, rzeczywiście używanego przez konkretną osobę.

Powróćmy do obiektu, który zainspirował nas do stworzenia niniejszego opracowania. Przedstawienia rzeźbiarskie z południowej kaplicy katedry legnickiej są jedynymi elementami nagrobka pary książęcej, które przetrwały do dzisiaj. Wpłynęła na to burzliwa historia grobowca, którą jak już wspomnieliśmy opisaliśmy niedawno (Wasiak, Badowska 2014). Zachowane figury również noszą na sobie piętno upływu czasu. Nie pozostał, na nich nawet ślad po polichromii, którymi zazwyczaj były pokrywane średniowieczne rzeźby (Kębłowski 1967: 39). Zewnętrzna warstwa piaskowca uległa częściowo erozji, wydaje się jakby starta, co powoduje, że część detali rzeźbiarskich jest dzisiaj niewidoczna. Dodatkowo zauważalne są liczne pęknięcia lub odpryski. Nagrobek z legnickiej katedry ukazuje Ludwika II w zbroi i jego żonę odzianą w fałdziste suknie. Obie figury to dzieła o wysokiej wartości artystycznej, choć wykonano je w odmiennym stylu. Prawdopodobnie także czas ich powstania jest różny (Kębłowski 1967: 39-72; Dobrowolski 1976; Skubiszewski 1960). Przyjmuje się, że podobizna Ludwika (Czechowicz 2003: 129) powstała około 1435 roku (data śmierci księcia to 30 kwietnia 1436). Czasem jako jej autora upatruje się kamieniarza sprowadzonego w 1414 roku z St. Denis (Czechowicz 2003: 129). Przedstawienie Elżbiety, tak odmienne w wyrazie od pierwszego, powstało zapewne w nie- 
co innych warunkach. W tym wypadku trudno jednak o konkretniejsze datowanie. Księżna zmarła w 1449 roku, w wieku 46 lat. W 1438 lub 1439 poślubiła Wacława I cieszyńskiego (Jasiński 2007: 196, 638), jednak do śmierci przebywała na dworze legnickim (Czechowicz 2003: 130; Szafrański 1972: 100). Zresztą małżeństwo z Wacławem, rozwiązane w 1445 lub 1446 roku (Czechowicz 2003: 130), nie należało do szczególnie zażyłych. Nie dziwi więc, że pochowana została u boku Ludwika II, w ufundowanym przez niego kościele Kartuzów (Jasiński: 196, 638). Charakterystyczna, dość jednolita bryła rzeźby ukazująca Elżbietę, stanowi jedyny jej wizerunek jaki omówimy.

Oddany w kamieniu, z wielością szczegółów rynsztunek księcia, stanowi niezwykle intrygujące zagadnienie do rozważenia. Sądzimy zatem, iż stosowniej będzie mu poświęcić osobne opracowanie, ukazujące go w szerszym kontekście bronioznawczym epoki. Pozwoli to zresztą na bliższe przyjrzenie się także innemu zbrojnemu wizerunkowi księcia, zamieszczonemu na jego Większej Pieczęci. Wykorzystamy zatem jedynie niektóre elementy tej rzeźby, dla porównania ich z wizerunkami analogicznych części ubioru ukazanych w innych źródłach. Jednakże głównym materiałem ikonograficznym ukazującym Ludwika, pozostaną dla nas trzy wizerunki utrwalone w malarstwie ściennym. Identyfikację osoby księcia na wszystkich tych polichromiach zawdzięczamy pracom Alicji Karłowskiej-Kamzowej (1979: 79). Jej badania wykazały, iż dzieła te, namalował w latach 1418-1428, artysta europejskiej klasy, sprowadzony właśnie przez Ludwika II'. Jak już zaznaczaliśmy, porównanie rożnych przedstawień, uznawanych przez naukę za wizerunki tej samej osoby, wydaje nam się zdecydowanie niezbędne.

Alicja Karłowska-Kamzowa zidentyfikowała jako podobiznę Ludwika II legnicko-brzeskiego przede wszystkim przedstawienie postaci z zakrystii brzeskiego kościoła katedralnego pw. św. Mikołaja, (ryc. 2). Badaczka ta odnajduje też podobiznę książęcą w scenie Pokłonu Trzech Króli w nawie kościoła w nieodległych od Brzegu Krzyżowicach. Ten sam artysta, Mistrz Brzeskich Pokłonów Trzech Króli, uwiecznił tam Ludwika II jako osobę asystującą najstarszemu Królowi, składającemu hołd Dzieciątku, (ryc. 3). Innym dziełem tego malarza, najprawdopodobniej wykształconego w kręgu flamandzko-franko-burgundzkim (Karłowska-Kamzowa 1975; 1979; 1984; 2004; Malarstwo Gotyckie: 91), jest, jak wskazuje jego współczesny „kryptonim artystyczny”, kolejna, unikalna i ważna dla naszych rozważań scena Hołdu Trzech Króli. Tę wyjątkowo

\footnotetext{
${ }^{1}$ W 1416 roku, w czasie pobytu w St. Denis, książę legnicko-brzeski wysłał do Legnicy artystę kamieniarza, który miał dokonać remontu wieży św. Jadwigi (Szafrański 1972).
} 
rozbudowana, ukazującą pełnię splendoru dworskiego (Karłowska-Kamzowa 1984: 91) scenę zakomponowano na południowej ścianie prezbiterium kościoła św. Wawrzyńca (obecnie św. Andrzeja) w Strzelnikach. Także i ta miejscowość położona jest niedaleko od Brzegu. Tu również w powierniku korony i miecza Sędziwego Króla, możemy dopatrzeć się Ludwika II (Karłowska-Kamzowa 2004:80-81), (ryc. 4). Ten kontekst ukazywania świeckich władców był zresztą praktykowany od XIV w. ${ }^{2}$. Co bardziej znaczące, w ten sposób sportretowany został także Zygmunt Luksemburski (Karłowska-Kamzowa 1979), z którym Piastowicz był blisko związany ${ }^{3}$. Należy wspomnieć, iż Franciszek Szafrański (1972: il. 8), autor wielce pożytecznej dla naszych rozważań biografii Ludwika II, prezentuje nawet kopię ilustracji ukazującej obu dostojników razem. Przedstawiono ich jako uczestników procesji Bożego Ciała w Konstancji w 1417 roku - książę legnicko-brzeski niósł wtedy miecz przed królem rzym$\operatorname{skim}^{4}$ (ryc. 5B). Potencjalnie niezwykle cenna dla nas rycina, pełni w dziele Szafrańskiego jedynie rolę poglądowej scenki. Zamieszczono tam bowiem wydaną drukiem w 1536 roku, kopię ilustracji pochodzącej z ok. 1465 roku, z manuskryptu Chronik des Konstanzer Konzils 1414-1418, Ulricha Richentala (kopia z Rosgartenmuseum w Konstancji, ryc. 5A). W omawianej scenie z Kroniki Soboru, wykonanej w drugiej połowie XV w., osobę noszącą królewski miecz podpisano jako księcia Saksonii („Herzog von Sachsen”). W jego to bowiem zastępstwie Ludwik dostapił zaszczytu niesienia miecza przed Zygmuntem Luksemburskim (Szafrański 1972: 9; Sokołowski 1907: 18-19; Chronik des...). Ilustracja ukazuje więc jedynie sytuację w jakiej Ludwik II wystąpił podczas procesji z udziałem króla, w dodatku w stylu ubioru jak i konwencji malarskiej pochodzącymi już w najlepszym wypadku z lat sześćdziesiątych XV w. Omawiany wizerunek pozostaje więc dla nas jedynie ciekawym faktem, pośrednio wiążącym się $\mathrm{z}$ biografią omawianego arystokraty.

We wszystkich przedstawieniach stworzonych przez Mistrza Brzeskich Pokłonów Trzech Króli, postać identyfikowana jako Ludwik II nosi stosunkowo krótki, sięgający ledwie do kolan strój. O ile wyobrażenia w scenach Hołdu Trzech Króli pokazują go jako pielgrzyma z podróżującego konno orszaku Trzech Króli, o tyle jego wizerunek z kościoła w Brzegu ma już nieco inny charakter. Wspólnie z osobą duchowną trzyma chustę św. Weroniki. Natomiast

\footnotetext{
${ }^{2}$ Karol IV, fresk z zamku w Karlsteinie za Karłowska-Kamzowa 1979. Przedstawienie to omawia też Sieradzki 1959.

${ }^{3}$ Uczestniczył też w wielu jego podróżach (Szafrański 1972: 43-63).

${ }^{4}$ Byli tam zresztą obecni także np.: Ścibor ze Ściborzyc, czy późniejszy teść Ludwika II - Fryderyk I, elektor brandenburski (Szafrański 1972: s. 59, il. 8).
} 
figura z nagrobka w katedrze św. św. Piotra i Pawła w Legnicy przedstawia wąsatego rycerza w zbroi (ryc. 1). Przyjrzyjmy się przede wszystkim trzeciemu, malarskiemu wyobrażeniu, które należałoby wiązać z księciem legnicko-brzeskim. Strój osoby asystującej Sędziwemu Królowi ukazany w Strzelnikach, jak już zaznaczyliśmy, jest kusy, lecz bogaty. Zarówno miecz, jak i korona, to precjoza Sędziwego Króla, znajdujące się w powiernictwie księcia, które nie są elementami związanymi z jego wizerunkiem. Puginał tarczowy, spoczywający przy lewym boku, omówiony bliżej przy okazji bronioznawczej analizy malowideł strzelnickich (Wasiak 2010: 36-40), stanowi prawdopodobnie własność księcia.

Mimo zniszczeń malowidła, zachował się wizerunek sukni wierzchniej spiętej dwoma pasami, sukni spodniej i różnokolorowych nogawic. Te ostatnie wyobrażono jako zieloną na prawej nodze i białą na lewej. Odzienie wierzchnie to luźna, fałdowana suknia - forma houppelande ${ }^{5}$ - z poszerzanymi rękawami zakończonymi siekanina (Turnau 1999: 164)6 „dębową”, z charakterystycznym, trójkątnym dekoltem z lamówką oraz siekanina „łuskową” zdobiącą dolną krawędź sukni. Ubiór ułożono na sylwetce spinając go wąskim paskiem w talii oraz ozdobiono kolejnym, szerokim, pasem biodrowym z puginałem tarczowym. Ciemną, spodnią suknię eksponują szerokie otwory rękawów i duży, trójkątny dekolt pod szyją. Trudno powiedzieć z jakim rodzajem stroju mamy tu do czynienia. Wyraźnie jednak widać stojący kołnierz, wąskie rękawy z odwiniętymi, jasnymi (podszewka?) mankietami, przypominającymi niemodne już w czasie powstania malowidła - bombardes ${ }^{7}$. Przedstawiona tak osoba unosi prawą ręką nakrycie głowy (mitra książęca?). Włosy namalowano jako jasne i dość długie.

Suknię przypominającą houppelande uwieczniono także na portrecie Ludwika II z podłucza niszy w południowej ścianie zakrystii kościoła św. Mikołaja w Brzegu, (ryc. 2). Także w tym wypadku odzienie sięga kolan, ma szerokie, podwinięte rękawy oraz trójkątny dekolt. Stan zachowania malowidła pozwala nam tym razem dojrzeć zarówno ciemną szatę spodnią z wąskimi, dopasowanymi rękawami jak i zielone nogawice oraz brązowe, sznurowane z boku

${ }^{5}$ „Houppelande - suknia dla obu płci wkładana przez głowę, o kroju kloszowym, obficie sfałdowana w talii paskiem, $\mathrm{z}$ wysokim stojącym kołnierzem i fantazyjnymi rękawami krojonymi z ćwiartek koła, szyta z tkanin jedwabnych lub sukna, nieraz podbita futrem; weszła w użycie we Francji ok. 1360 r. później także w pozostałych krajach i w Polsce (...)” (Turnau 1999: 70). Podobna definicja (Gutkowska-Rychlewska 1968: 867).

${ }^{6}$ Siekanina - w piętnastym wieku naszycie na ubiorze, ozdobne nacięcia, falbanki i frędzle.

7 ,Bombardes - kloszowe zakończenie wąskiego rękawa przy ubiorach męskich i kobiecych w pocz. XV w.; zakrywały całą dłoń lub tylko do palców" (Gutkowska-Rychlewska 1968: 196, 861). 
buty z krótką cholewką. Wyraźnie widać gładko ogoloną twarz sportretowanej osoby, co pozwala dostrzec zdecydowanie wydatny nos, którego kształt robi wrażenie celowego utrwalenia cechy osobistej modela. Wizerunek postaci uzupełniają jasne lub brązowe, falujące lub kręcone włosy, oraz mitra książęca. Nie widać żadnego przepasania.

Krzyżowicki wizerunek kojarzony z księciem legnicko-brzeskim, prezentuje podobny do obu opisanych wcześniej schemat odzienia. Krótkie suknie -wierzchnia i spodnia - uzupełniają nogawice i buty sięgające „za kostkę”. Stan zachowania nie pozwala na ocenę wyglądu twarzy, widać jednak tiarę książęca i fragment prawdopodobnie jasnych, kręconych włosów (ryc. 3). Strój uzupełnia szeroki pas. Suknia wierzchnia wydaje się przylegać do sylwetki od ramion do pasa, po czym rozkloszowuje się wyraźnie. Zaopatrzona jest w centralne rozcięcie z przodu i wykończenia krawędzi lamówką (wywinięcie podszewki?). Także ona ma trójkątny dekolt, a rękawy odsłaniają przedramiona okryte obcisłym rękawem szaty spodniej. Forma rękawów odzienia wierzchniego jest bardzo interesująca. Już na pierwszy rzut oka wydaje się, że są one zawinięte, tak jak w bardzo zresztą podobnej, szacie Piłata na kwaterze Tryptyku z Ptaszkowej z ok. 1440 roku (datowanie tryptyku Gadomski 1984: 107n, 126, il. 6, 9; 2004: 262; Małkiewiczówna 2007: 79), (ryc. 6). Krystyna Turska (1987: 125, 128, il. 77) przytacza ostatni wizerunek, opisując ten ubiór jako jopulę. W Krzyżowicach, przy prawym rękawie księcia, możemy jednak zaobserwować pas materiału przypominający czternastowieczne tippets (Gutkowska-Rychlewska 1968: 156, 158, 196; Houston 1996: 108-109)8 , używane jeszcze czasem także w początkach XV wieku' ${ }^{9}$. Sądzimy, że widoczny w Krzyżowicach pas materiału w okolicy podwinięcia rękawa uznać należy za osobny fragment płaszcza jednego z Trzech Króli, co łatwiej dostrzec na kolorowej reprodukcji malowidła (ryc. 7). Trudnym do zauważenia, ale bezsprzecznie realistycznie oddanym detalem stroju, na który należy zwrócić uwagę są podwiązki na nogawicach, wystające częściowo spod krótkich szat (ryc. 3). Na ich wizerunku dopatrzeć można się metalowej sprzączki i końcówki paska.

W trzech omówionych przedstawieniach, książę legnicko-brzeski ukazany został za każdym razem w nieco innej sukni wierzchniej, jednak cały ubiór, jak już zaznaczyliśmy, zawsze dobrany jest według bardzo podobnego stylu. Dwukrotnie, w Strzelnikach i w Brzegu wyobrażono Ludwika w krótkiej,

\footnotetext{
${ }^{8}$ Tippets (ang.) lub courdieres (fr.) - ozdoba krótkich rękawów w strojach męskich i kobiecych w postaci zwisających, wydłużonych pasów futra lub sukna, modna w II poł. XIV w.

${ }^{9}$ Czego dobrym przykładem jest kobieca suknia ze sceny zaręczyn na kwietniowej karcie Bardzo Bogatych Godzinek Księcia de Berry, w ilustracji braci Limburg, powstałej ok. 1411-1416 - Dulewicz 1986; 234; Eörsi 1986: 31.
} 
luźnej sukni typu houppelande. Szczególnie interesujące jest dla nas wyobrażenie strzelnickie, o szerokich rękawach zdobionych siekanina (ryc. 4). Maria Gutkowska-Rychlewska sugeruje, iż to rozwiązanie pojawiło się w modzie niemieckiej najwcześniej w latach dwudziestych XV w. (Gutkowska-Rychlewska 1968: 185; Boucher 1965: 205). Tego typu odzienie, zaadaptowane zostało następnie we Francji, gdzie jak odnotowuje badaczka, pojawia się często w okolicach 1430 roku w inwentarzach jako robe á la façon d'Allemagne (Gutkowska-Rychlewska 1968). Szczyt popularności przeżywa ona około roku 1440, by stać się nieco passé około roku 1450. Sytuację komplikuje nieco fakt, iż wspomniana badaczka prezentuje „wycinankę w liście”, na ilustracji datowanej na lata 1407-1410. Podobne zdobienie płaszcza znane jest też z nagrobka zmarłego ok. 1344 roku Williama of Hatfield (Crowfood, Pritchard, Stanilad 2006: 195, fig. 178). Zarówno te przykłady ikonograficzne, jak i choćby znalezisko jednego takiego elementu, datowane na drugą ćwierć XIV w. (Crowfood, Pritchard, Stanilad 2006: 194-195, fig. 177), ukazują wcześniejszą krótszą formę siekaniny „w dębowe liście”. Zaś opinia Marii Gutkowskiej-Rychlewskiej, nie negowana już od prawie osiemdziesięciu lat, odnosi się prawdopodobnie jedynie do form wycięć podłużnych, taśmowatych. Przy czym, linia wycięcia nie zawsze musi dokładnie przypominać krawędź liścia dębu. Dobrym przykładem tego zjawiska są siekaniny rycerza Chrystusa z Ottarza Gandawskiego z ok. 1432 roku (Limentani Virdis, Pietrogiovanna 2004: 51-70) (ryc. 8), gdzie kompozycja cięć przypomina raczej pęki morszczynu (fucus). Podobnie, ok. 1435 roku Konrad Witz zakomponował zdobienia szaty Benajasza (ryc. 9), w Abiszaj, Subotaj $i$ Benajasz przed Dawidem, Tablice Ołtarza Zwierciadła Zbawienia (obecnie w Kunstmuseum Basel, Bazylea). Całą zaś kolekcję „mody wycinankowej" w różnych omawianych formach możemy obejrzeć w Wersalu w Musée National du Château, w scenie Polowanie z sokotem na dworze Filipa Dobrego, zdrugiej ćwierci XV w. (za Baucher 2009: 168-169, il. 273; Gutkowska-Rychlewska 1968: 182) (ryc. 10).

Należy też podkreślić, iż szerokie rękawy o trapezowatym obrysie, czy łuskowate wręby w dolnej krawędzi ubioru to cechy spotykane dość często w modzie europejskiej jeszcze pod koniec XIV w (Houston 1996: 106-120; Gutkowska-Rychlewska 1968: 175-185). Niezwykle popularne źródło ikonograficzne jakim są Bardzo Bogate Godzinki Księcia de Berry, ukazują zdobione wrębami uplany (houppelandes), przy czym wycinana dekoracja przypominająca nieco brzeg liścia dębu pojawia się wyłącznie przy zdobieniach kapturów. Zresztą, siekanina w geometrycznej formie, zdobiąca tę cześć odzieży znana jest także jeszcze z XIV w. 
W Krzyżowicach, mamy do czynienia z suknią analogiczną do ubioru Piłata z Tryptyku z Ptaszkowej (ryc. 6). Można ją również skojarzyć z odzieniem noszonym przez jednego z Trzech Króli (postać zwracającą się do Młodego Króla) na malowidle z południowej ściany prezbiterium kościoła w Strzelnikach (ryc. 11). Oba, formalnie różne typy sukni, obszerna i fałdzista oraz dopasowana, w niemal identyczny sposób eksponują szatę spodnią. Trójkątny dekolt ukazuje jej kołnierz, widoczne są także obcisłe rękawy spodniego odzienia na odcinku od łokcia do mankietu. Pas widoczny w Krzyżowicach i w Strzelnikach można uznać za podobny, być może nawet taki sam, jak wyobrażony na figurze nagrobnej z katedry legnickiej.

Kolor zielony, bądź turkusowy, pojawia się dość często. Zielone są nogawice na polichromii w Krzyżowicach (ryc. 3) i (tylko jedna) w Strzelnikach (ryc. 4). Nogawice ukazane w Brzegu także noszą kolor, który można by określić (ze stosowną ostrożnością) jako zielony, turkusowy lub ewentualnie niebieski (ryc. 2). Niezwykle ważną cechą ubioru władcy są ",półwysokie” buty, sięgające za kostkę, o górnej krawędzi cholewki bardzo podobnej zarówno na wyobrażeniu z Brzegu jak i z Krzyżowic.

Jesteśmy w stanie wyróżnić cechy ubioru Ludwika II składające się na jego charakterystyczny wizerunek i pozostające jednocześnie w konwencji mody z epoki. Główny zestaw ubioru tego Piasta ukazywany przez tego samego artystę pojawia się w bardzo podobnej formie we wszystkich trzech przedstawieniach. Widzimy tu krótki strój wierzchni do kolan, z trójkątnym dekoltem, odsłaniający spodni w obrębie przedramion i kołnierza. Ukazują to zarówno sceny związane z Hołdem Trzech Króli jak i wyobrażenie księcia trzymającego chustę św. Weroniki. Można zatem założyć, iż te elementy ubioru są w jakimś stopniu charakterystyczne dla tej osoby, lub takimi się wydawały w opinii twórcy malowideł. Na podstawie porównania dzieła brzeskiego i krzyżowickiego, trzeba by ten obraz uzupełnić o sznurowane z boku buty, o sięgającej za kostkę cholewce, której profil wycięty jest w kształt „,rybiego ogona”. Dobrze rozpracowane schematy i zdjęcia podobnych butów pochodzących z początków XV w., zamieszczono w opracowaniu znalezisk londyńskich (Grew, Mitford, Neergaard 2004: il. $59,68,69,70,108)$, co pozwala nam na poglądową rekonstrukcję obuwia, które mogło posłużyć jako inspiracja dla Mistrza Brzeskich Pokłonów Trzech Króli (ryc. 2). Interesujące, że strój postaci, które można identyfikować z podobiznami Ludwika II legnicko-brzeskiego, niekoniecznie różni się mocno wystawnością od ubioru innych, dobrze wyeksponowanych postaci z orszaku Trzech Króli. Odzienie Króla w średnim wieku w zasadzie nie odbiega specjalnie swoim stylem od ubioru krzyżowickiego ,portretu” Ludwika II. 
Zdecydowaliśmy się na stworzenie dwóch rekonstrukcji graficznych, będących próbą utrwalenia wizerunku Ludwika II w dwóch odmianach sukni wierzchnich. Oparliśmy się przede wszystkim na podobiznach z Krzyżowic i ze Strzelnik. Krzyżowicką szatę księcia (ryc. 12) uznaliśmy za wariant dopasowanej „sukni Piłata z Ptaszkowej”, którą za Krystyną Turską należałoby nazwać jopula. Jej dopasowanie w talii rozwiązano zapewne za pomocą ukrytego zapięcia $z$ boku lub przodu ubioru. Zarys dekoltu sugeruje, iż raczej nie była to szata rozpinana na całej długości z przodu, co utrudniałoby eleganckie ułożenie wykończenia dekoltu. Nie zaznaczyliśmy także sposobu zapięcia szaty spodniej, choć ukazaliśmy jego linię, podobnie jak orientacyjne miejsce wszycia kołnierza. Być może zapinano ją na guziki, podobnie jak analogiczny ubiór namalowany w Ptaszkowej (ryc. 6). Pas biodrowy zamieszczony na rekonstrukcji to kopia przedstawionego na nagrobku z katedry legnickiej (ryc. 14), podobnie jak mitra książęca (ryc. 15). Buty wzorowano na typowych przykładach obuwia z bocznym sznurowaniem, znanego ze znalezisk archeologicznych. Przydano im wykończenie cholewki znane z podobizn księcia z Brzegu i z samych Krzyżowic ${ }^{10}$. Podwiązki zaopatrzono w silniej wyróżniającą się końcówkę paska dla podkreślenia jej obecności. Miecz ukazany na polichromiach krzyżowickich zaopatrzono w sześciokątną głowicę, wyraźnie widoczna jest tam też silnie zwężająca się ku sztychowi głownia, oraz taszka. Postać na ilustracji ukazano symbolicznie, raczej jako modela, pozującego do sceny Pokłonu Trzech Króli. Trudno bowiem do dziś ustalić właściwy dla czasu powstania portretu wizerunek oblicza księcia.

Rekonstrukcja stroju ze Strzelnik (ryc. 13) wykonana została na podobnej zasadzie. Postać nie miała być portretowym oddaniem Ludwika II, choć modelowi przydano m.in. charakterystyczny, wydatny i długi nos, znany z wszystkich jego malarskich przedstawien, oraz wizerunku nagrobnego. W tym ostatnim wypadku możemy się jedynie domyślać jego pełnego kształtu, jednak proporcje twarzy wyraźnie utrwalają znaczną długość nosa. Mitrę książęca, buty i pas odtworzono na identycznej zasadzie jak w przypadku „rekonstrukcji krzyżowickiej”, przydając modelowi miecz podobny do trzymanego przez Ludwika w strzelnickiej scenie Hołdu Trzech Króli. Szata spodnia, być może zapinana na guziki, podobnie jak spodni „ubiór Piłata ptaszkowskiego”, ukazana została z podkreśleniem dość intrygująco zaznaczonych w Strzelnikach mankietów. Ukazanie ich jako ewentualnych bombardes, uznaliśmy za zbyt ekstrawaganckie w zestawieniu z suknią wierzchnią. Potencjalną możliwość takiego rozwiązania usprawiedliwiałoby,

\footnotetext{
${ }^{10}$ Przy czym stan malowideł krzyżowickich nie pozwala na dokładną analizę detali obuwia i sposobu sznurowania.
} 
co prawda, piętnastowieczne przedstawienie bombard (ryc. 17). Nie uzasadniałoby ono jednak zestawienia tego rozwiązania z ozdobną suknią wierzchnią opartą o wzór houpppelande. Ta zaś stanowi najważniejszy element wizerunku omawianej postaci. Ozdobne wycięcia jej charakterystycznych rękawów rozpoczynają się wysoko w okolicy ramienia, by niżej komponować się wzdłuż linii prawdopodobnie trapezoidalnego rękawa szaty. Podobne rozwiązanie możemy zaobserwować choćby w szacie Benajasza namalowanej przez Konrada Witza (ryc. 9). Układ fałd szaty strzelnickiej zaprojektowano prawdopodobnie w korelacji z wrębami ukazanymi na jej dolnej krawędzi. W przypadku tego rodzaju, ozdobnej szaty, starannie rozplanowane fałdowanie zdaje się być dobrze potwierdzone przez ikonografię średniowieczną (ryc. 10). Warto przy tym podkreślić, iż obserwujemy na tym przedstawieniu szatę wierzchnią modną i bardzo nowoczesną, pasującą do ekstrawaganckiego i światowego stylu życia Ludwika II.

Jedyne wyobrażenie Elżbiety z Hohenzollernów, księżnej legnicko-brzeskiej jakim dysponujemy, to wspominany nagrobek z katedry św. św. Piotra i Pawła w Legnicy (ryc. 1).

Jak już powyżej wspominaliśmy, pośmiertne wyobrażenie Elżbiety dotarło do naszych czasów nieco okaleczone. W wyniku erozji nieco zatarte zostały regularne i piękne rysy księżnej, podobnie jak drobniutkie falbanki czepca. Elementu zdobiącego przepaskę na czole możemy się jedynie domyślać, podobnie jak zakończenia taśmy wiążącej płaszcz. To ostatnie zniszczenie powstało na skutek rozłupania posagu na linii ramion. Podobne pękniecie jest widoczne na krawędzi twarzy i szyi. Janusz Kębłowski wspomina o jeszcze jednym, niewidocznym pęknięciu z tyłu posagu (Kębłowski 1967: 40). Ledwo widoczne są obecnie zdobienia pasa oraz pierścień na palcu lewej dłoni. W stworzeniu spoczywającym u stóp księżnej z wielkim trudem możemy domyślać się psa.

Księżna odziana jest w, co najmniej, dwie suknie spływające wąskimi równymi fałdami do ziemi, tak że spod nich widoczne są jedynie noski butów. Talia zaznaczona jest wą̧skim skórzanym pasem, którego końcówka sięga, zgodnie z ówczesną modą, do poziomu kolan. Na ramiona został zarzucony długi płaszcz zawiązany pod szyją, podobnie jak suknie drobno fałdowany. Głowę okrywa czepiec, a z lewej ręki zwisa paternoster. Regularne fałdy szat oraz ich płytkie, wręcz linearne wykonanie nasuwają skojarzenia z greckimi rzeźbami archaicznymi lub romańskimi (Kębłowski 1967: 44) (ryc. 16).

Twórcy dotychczasowej literatury nie mają problemu w rozpoznaniu nakrycia głowy księżnej, zgodnie uznając je za czepiec określany jako kruseler (Drążkowska 2012; Gutkowska-Rychlewska 1967; Turska 1987: 82-83), popularny w Europie Środkowej w XIV i XV wieku, wywodzący się z Czech, 
skąd przywędrował na Śląsk (Gutkowska-Rychlewska 1968: 161-163). Przybierał on różne formy. Podstawowa to płócienna, wycięta w kształt półkola chusta wykończona obszyciem z falbanek. Egzemplarz noszony przez księżną jest późną formą tego czepca, w której twarz okala wałek, prawdopodobnie usztywniony, składający się z wielu falbanek (Drążkowska 2012: 82-83), kilka rzędów falbanek zdobi spływającą na ramiona dolną część chusty (ryc.18). Przykład takiego czepca możemy znaleźć choćby na znanej hermie Marii Magdaleny (ok. 1370 r.) z kościoła w Stopnicy (Turska 1987: 98, il. 51) czy na niemieckiej tapiserii przedstawiającej gry i zabawy z XV wieku (Real Biblioteca de San Lorenzo de El Escorial, PG 22, za Bartlett 2002: 127) (ryc. 17).

Tego typu nakrycie głowy często pojawia się w śląskiej późnośredniowiecznej ikonografii w zestawieniu z suknią typu surcot (Gutkowska-Rchlewska 1968: 281). To suknia bez rękawów z głębokim wycięciem pod pachami, noszona już w XIII wieku (Turnau 1999: 172). Stąd zapewne Maria Gutkowska-Rychlewska (1968: 281) w swojej znakomitej Historii Ubiorów, interpretuje suknię wierzchnią księżnej jako ten typ szaty i datuje na około 1350 rok. W tym samym dziele Gutkowska-Rychlewska zamieszcza inny wizerunek kobiety noszącej surcot w połączeniu z kruselerem, również z połowy XIV stulecia (Gutkowska-Rychlewska 1968: 145). Na datowanie stroju niewątpliwie wpłynęło dotychczasowe mylne łączenie go z księżną Anną Cieszyńską zmarłą w roku 1357 (ryc. 19).

Z teorią Gutkowskiej-Rychlewskiej zgadza się Krystyna Turska (1987: 99), nazywając suknię księżnej typem surcot ouvert, czyli późniejszą formą tego ubioru, noszoną w XIV i XV wieku. Natomiast datowanie stroju Turska przesuwa na rok około 1400, ze względu na nowsze ustalenia dotyczące nagrobka (Kębłowski 1967: 44; 1971: 174-178). Autorka nie znajduje podobnych strojów w modzie zachodniej ani na terenie Polski w dostępnych źródłach z tego okresu (Turska 1987: 100).

Rozważania na temat rodzajów sukni surcot, datowania ich form i ewentualne zwrotne datowanie na ich podstawie nagrobka, okazało się jednak ślepa ścieżką. W wyniku szczegółowych oględzin rzeźby, uznaliśmy, że doszło do nieporozumienia. Linie układające się w kształt podobny do surcot, w rzeczywistości wynikają z oddania $\mathrm{w}$ kamieniu zupełnie innego zestawu garderoby. Można by nawet rzec, iż jest to kompozycja „wręcz przeciwna” do dotychczas rozpoznawanej. Warstwy odzieży wyrzeźbione przez artystę układają się w innej kolejności niż dotychczas sądzono (ryc. 20). Księżna na sukni spodniej nosi rodzaj otwartego z przodu płaszcza, z krótkimi, sięgającymi łokci rękawami. Odsłania on spodnią suknię w taki sposób, iż może ona przypominać surcot. 
Jednak owe łukowate linie nie zatrzymują się na linii bioder, ale schodzą niżej, wyraźnie nad pasem i pod złożonymi rękami Elżbiety kończąc się gdzieś powyżej kostek (co widać na ilustracji ryc. 21). Na ten nietypowy „płaszczyk”, zarzucony został, klasyczny dla mody późnego średniowiecza, półkolisty płaszcz zawiązany wąską taśmą pod szyją i wykończony również wąską lamówką, spod której wychodzą bardzo drobne fałdy, spływające aż do ziemi.

Analiza przedstawienia spodniej sukni Elżbiety także przynosi ciekawe obserwacje. Jej rękawy są dość szerokie i bufiaste, zmarszczone wąskimi mankietami przy nadgarstkach. Dekolt tej sukni jest wycięty w kształcie litery „V” i lamowany. Fałdy, interpretowane przez Krystynę Turską jako plisy są raczej wynikiem ściągnięcia, zapewne szerokiej sukni, wysoko w talii pasem. Zauważalne są bowiem właśnie tuż nad nim i biegną aż do samego dołu sukni. Ich rytmiczny i równy układ wydaje się efektem typowym dla zmarszczenia w pasie sukien rodzaju houppelande. Nie należy tego utożsamiać z zabiegiem krawieckim jakim jest współczesne zaszywanie czy zaprasowywanie plis w ubiorach kobiecych. Wydaje nam się, że spodnią suknię księżnej można uznać właśnie za rodzimą wersję wspomnianej wyżej houppelande. Krystyna Turska (1987: 158, il. 96b) przywołuje suknię świętej z nowosądeckiego ołtarza (ok. 1450 r.) jako przykład polskiego odzienia inspirowanego houppelande, z charakterystycznym, trójkątnym dekoltem (ryc. 22).

Warto może przyjrzeć się jeszcze głowie księżnej. Spod dominującego swym rozmiarem czepca, bezsprzecznie rozpoznanego jako kruseler, widoczna jest na czole wąska opaska, a w jej centralnym punkcie zachowane są w tej chwili jedynie ślady po kunsztownej ozdobie. Być może był to diadem książęcy. Niewielkie pasma włosów wychodzące spod opaski skrywają się na wysokości uszu pod kruselerem, tak, że niestety, trudno również zinterpretować sposób ich uczesania. Nieco długa i szeroka szyja mąci harmonię idealnego piękna całej postaci. Częściowo jest to niefortunny skutek obrażeń jakich doznała figura (pęknięcie, czy raczej należałoby powiedzieć rozłupanie, na linii ramion oraz na krawędzi twarzy i szyi). Bardziej wnikliwe studiowanie rzeźby pozwala zauważyć delikatną linię biegnącą pod brodą i ginącą pod czepcem, której w połączeniu z lekko nienaturalnym wyglądem szyi trudno nie skojarzyć z welonem jaki zapewne nosiła księżna brzesko-legnicka (ryc. 23).

Paternoster, który księżna trzyma w ręce można interpretować jako symbol jej znacznej pobożności. W sznurze paciorków, z których każdy odpowiada jednemu „ojcze nasz”, możemy dopatrzeć się dodatkowych elementów. Jednym z nich jest gałązka koralu, która według ówczesnych wierzeń miała symbolizować stan zdrowia noszącej ją osoby (Kębłowski 1967: 71). Pozostałe dwa 
elementy urozmaicające paternoster są dziś trudne do zinterpretowania ze względu na zły stan zachowania nagrobka. Być może były to pamiątki pielgrzymie w postaci muszli lub medalików (ryc. 24).

Przeprowadzona przez nas analiza malarskich wizerunków księcia Ludwika II legnicko-brzeskiego pozwala choć w części podjąć próbę rekonstrukcji stroju noszonego przez księcia jak i środowiska w jakim się obracał. Trzy omówione powyżej polichromie nie przedstawiają identycznego ubioru władcy, ale ich styl jest do siebie mocno zbliżony. $\mathrm{Z}$ zestawienia ich ze sobą możemy wyłonić elementy wspólne w postaci szczupłej męskiej sylwetki z podkreśloną talia, w sięgającym kolan, ozdobnym stroju z fantazyjnymi rękawami i trójkątnym dekoltem, w wąskich, kolorowych nogawicach i butach sięgających za kostkę. Dodatkowo, biorąc pod uwagę opinie M. Gutkowskiej-Rychlewskiej i datowanie malowideł ze Strzelnik (1418-1428), możemy uznać Ludwika II za jednego z prekursorów mody na robe á la façon d'Allemagne. Znakomicie uzupełnia to jego obraz jako światowca, podróżnika, fascynata kultury rycerskiej i przyjaciela oraz znaczącego dworzanina Zygmunta Luksemburskiego.

Zaobserwowany schemat postanowiliśmy zwizualizować i przedstawić $\mathrm{w}$ formie graficznej rekonstrukcji. Jako pomoc w uzupełnieniu detali ubioru pozwoliliśmy sobie wykorzystać figurę nagrobną księcia z katedry legnickiej. Rekonstrukcje te traktujemy jako bardziej precyzyjne ukazanie naszych obserwacji i wniosków, nie obciążone wieloznacznością zawiłych opisów i samej, dość niejednorodnej terminologii kostiumologicznej.

Ubioru Elżbiety z Hohenzollernów z braku innych znanych przedstawień, niestety, nie możemy poddać podobnej analizie porównawczej. Dostarcza on nam jednak nie mniej wrażeń niż liczniejsze wizerunki jej małżonka. Przede wszystkim, okazało się, iż księżnę wyobrażono w zupełnie innym stroju niż opisywały dotychczasowe badania kostiumologiczne. Zdezaktualizowało to jeden z częściej przywoływanych przykładów ikonograficznych sukni typu surcot, powodujący zresztą niemałe zamieszanie $\mathrm{w}$ datowaniu zarówno przedstawienia jak i samej sukni (Czechowicz 2003: 128-130; Gutkowska-Rychlewska 1968: 281; Turska 1987: 100). Jednocześnie pojawił się wśród źródeł ikonograficznych nowy, nie znany rodzaj sukni piętnastowiecznej. Zarówno te, jak i pozostałe, mniej zaskakujące ale równie ważne obserwacje, wskazują na wielką wagę porównawczych badań ikonograficznych obejmujących także, jakby się wydawało, dobrze opracowane źródła. Jak podkreślaliśmy, ubiór księżnej nadal pozostaje w wielu aspektach dość zagadkowy. Być może przyszłe prace porównawcze pozwolą na lepsze jego poznanie. 
Wizerunki strojów pary książęcej, traktujemy przede wszystkim jako utrwaloną przez sztukę wizję artystyczną, jednak zdecydowanie realistyczną i posiadającą dużą wartość dokumentacyjną. Sądzimy, iż oprócz odkryć, nasze analizy przyniosły także nowe pytania, w tym związane z problemem identyfikacji wyobrażeń ikonograficznych oraz krytyki tego typu źródeł.

mgr Katarzyna Badowska

Uniwersytet Łódzki

Wydział Filozoficzno-Historyczny

Instytut Archeologii

ul. Uniwersytecka 3

90-137 Łódź mgr Wojciech Wasiak

Uniwersytet Łódzki

Wydział Filozoficzno-Historyczny

Instytut Archeologii

ul. Uniwersytecka 3

90-137 Łódź

\section{Bibliografia}

Źródła

Chronik des... Chronik des Konstanzer Konzils, 1465, Hs. 1, Bl. 1r-150r, Konstanz, Rosgartenmuseum. (Potwierdzona kopia digitalizowana Wikicommons: http://commons.wikimedia.org/wiki/Category:Konstanzer_Richental_ Chronik?uselang=de, (dostęp: lipiec 2013).

Dokumentacja konserwatorska z 2005 roku, Wojewódzki Ośrodek Ochrony Zabytków w Opolu.

Hausbuch der Nürnberger Zwölfbruderstftung, ok. 1425, Norymberga, Stadtbibliothek Nürnberg, $317.2^{\circ}$, f $13 \mathrm{r}$, http://www.nuernberger-hausbuecher.de/ (dostęp: lipiec 2013).

Opracowania

Bartlett R. (2002), Panorama średniowiecza, Arkady, Warszawa.

Boucher F. (1965), Historie du costume en ocident de l'antiquite a nos jours, Flammarion, Paryż.

Boucher F. (2009), Historia mody. Dzieje ubiorów od czasów prehistorycznych do końca XX wieku, Arkady, Warszawa.

Crowfoot E., Pritchard F., Stanilad K. (2006), Textiles and Clothing c. 1150-1450. Medieval Finds from Excavations in London, The Boydell Press, Woodbridge.

Czechowicz B. (2003), Nagrobki późnogotyckie na Ślasku, Wydawnictwo UW, Wrocław. 
Dobrowolski T. (1976), Stan badań nad nagrobkami ksiażat piastowskich i innymi średniowiecznymi pomnikami Ślaska (Na podstawie prac wydanych po roku 1945), „Roczniki Sztuki Śląskiej”, t. X, s. 147-171.

Drążkowska A. (2012), Ozdoby i nakrycia głowy na ziemiach polskich do końca XVIII wieku, Wydawnictwo naukowe UMK, Toruń.

Dulewicz A. (1986), Stownik sztuki francuskiej, wyd. III, Wiedza Powszechna, Warszawa.

Eörsi A. (1986), Gotyk międzynarodowy, Wydawnictwo Artystyczne i Filmowe, Warszawa.

Gadomski J. (1981), Gotyckie malarstwo tablicowe Małopolski 1420-1470, PWN, Warszawa.

Gadomski J. (2004), Malarstwo tablicowe w Matopolsce, [w:] Malarstwo Gotyckie w Polsce, t. 1, Synteza, red. A. S. Labuda, K. Secomska, DiG, Warszawa, s. 251-306.

Grew F., Mitford S., Neergaard M. (2004), Shoes and Pattens, Medieval Finds from Excavations in London, The Boydell Press, Woodbridge.

Gutkowska-Rychlewska M. (1968), Historia ubiorów, Ossolineum, Wrocław.

Houston M. G. (1996), Medieval Costume in England and France. The 13th, 14th and 15th Centuries, Dover Publications, New York.

Jasiński K. (2007), Rodowód Piastów Ślaskich. Piastowie wrocławscy, legnicko-brzescy, świdniccy, ziębiccy, głogowscy, żagańscy, oleśniccy, opolscy, cieszyńscy i oświęcimscy, wyd. 2 popr., Avalon, Kraków.

Kaczmarek R. (1991a), Gotycka rzeźba w Legnicy, [w:] Kultura artystyczna dawnej Legnicy, red. J. Harasimowicz, Wydawnictwo Instytutu Śląskiego, Opole, s. $41-62$.

Kaczmarek R. (1991b), Stowarzyszenie „Obroży Psa Gończego”. Z dziejów świeckich zakonów rycerskich na Ślasku, „Poznańskie Towarzystwo Przyjaciół Nauk”, nr 108, s.13-23.

Karłowska-Kamzowa A. (1975), Brzeskie malowidła ścienne z pierwszej połowy XV wieku. Zagadnienia zwiazków ślasko-burgundzkich u schyłku średniowiecza, „Opolski Rocznik Muzealny”, nr 6, s. 193-230.

Karłowska-Kamzowa A. (1979), Malarstwo Ślaskie 1250-1450, Ossolineum, Wrocław.

Karłowska-Kamzowa A. (1984) Ślask, [w:] Gotyckie malarstwo ścienne w Polsce, red. J. Domasławski, A. Karłowska-Kamzowa, M. Kornecki, H. Małkiewiczówna, Wydawnictwo naukowe UAM, Poznań, s. 90-91.

Karłowska-Kamzowa A. (2004) Malarstwo ścienne na Ślasku, [w:] Malarstwo Gotyckie w Polsce, t. 1, Synteza, red. A. S. Labuda, K. Secomska, DiG, Warszawa, s. 79-81.

Kębłowski J. (1967), Nagrobek księcia Wacława i Anny w Legnicy, „Szkice Legnickie”, t. IV, s. 39-72. 
Kębłowski J. (1971), Pomniki Piastów ślaskich w dobie średniowiecza, Ossolineum, Wrocław.

Krüger R. (1974), Dawne niemieckie malarstwo tablicowe, Arkady, Henschelverlag, Warszawa-Berlin.

Labuda A. S., Secomska K. red. (2004), Malarstwo Gotyckie w Polsce, t. 2, Katalog zabytków, DiG, Warszawa.

Limentani Virdis C., Pietrogiovanna M. (2004), Arcydzieła malarstwa ołtarzowego, Arkady, Warszawa.

Małkiewiczówna H. (2007), O gotyckich tryptykach z kościoła w Ptaszkowej, [w:] Artifex Doctus. Studia ofiarowane profesorowi Jerzemu Gadomskiemu w siedemdziesiątą rocznicę urodzin, red. W. Bałus, W. Walanus, M. Walczak, tom II, PAU, UJ, Kraków, s. 75-89.

Sieradzki J. (1959), Polska wieku XIV. Studium z czasów Kazimierza Wielkiego, PWN, Warszawa.

Skubiszewski P. (1960), Nagrobek Henryka II we Wrocławiu i problem ślaskiej rzeźby nagrobkowej w II połowie XIV wieku, Rozprawy Komisji Historii Sztuki, t. II, Prace Komisji Historii Sztuki, red. T. Broniewski, Ossolineum, Wrocław, s. 79-116.

Sokołowski M. (1907), Ścibor ze Ściborzyc i Pippo Spano tudzież kilka słów o kronice Ulricha v. Richental, Akademia Umiejętności, Kraków.

Szafrański F. (1972), Ludwik II brzesko-legnicki. Feudat ślaski z doby późnego średniowiecza, Ossolineum, Wrocław.

Turnau I. (1999), Słownik ubiorów. Tkaniny, wyroby pozatkackie, skóry, broń $i$ klejnoty oraz barwy znane $w$ Polsce od średniowiecza do poczatku XIX $w$. Wydawnictwo Naukowe Semper, Warszawa.

Turska K. (1987), Ubiór dworski $w$ Polsce $w$ dobie pierwszych Jagiellonów, Ossolineum, Wrocław.

Wasiak W. (2010), Gotyckie malarstwo ścienne z kościoła św. Wawrzyńca w Strzelnikach, woj. opolskie, jako źródło do historii uzbrojenia, niepublikowana praca magisterska, archiwum Instytutu Archeologii Uniwersytetu Łódzkiego.

Wasiak W., Badowska K. (2014), Nagrobek Wacława I i Anny Cieszyńskiej czy Ludwika II Legnicko-Brzeskiego i Elżbiety z Hohenzollernów?, [w:] Królowie i biskupi, rycerze i chłopi - identyfikacja zmarłych, Funeralia Lednickie, spotkanie 16, red. W. Dzieduszycki, J. Wrzesiński, SNAP Oddział w Poznaniu, Poznań, s. $119-145$. 
SUMmary

\section{CLOTHING LUDWIG II OF LEGNICA AND BRZEG AND HIS WIFE, ELIZABETH OF HOHENZOLLERN}

This paper focuses on the appearance and dress of two important to medieval Silesia persons, duke Louis II of Brzeg-Legnica and his second wife, Elisabeth of Hohenzollern. Our reconstruction is based on three preserved medieval polychromes depicting the duke, and on his tombstone. Relics of the tomb, sculptures of duke Louis and his wife Elisabeth, are exhibited in the Cathedral Church of St Peter and St Paul in Legnica. Polychromes believed to be images of Louis II are in parish churches of Strzelniki, Krzyżowice and in St Nicholas Church in Brzeg. They were painted by the so called Master of Adoration of the Magi - skilled artist probably brought to Silesia by duke Louis II from Burgundy or Flanders. After examining duke's clothes from the paintings, we come to the conclusion, that there are two different types of dress he was supposed to wear. Both splendid but short, barely reaching knees. One seems to be tightly fitted at chest and flared at waist. This kind of dress is often called jopula. The other dress is wide and loose, pulled in at waist with a belt. It has also wide sleeves decorated with a cut-out in a shape of oak leaves. This sort of dress is very similar to the gown which was quite popular in medieval Western Europe and we know it as houppelande. In both cases costume is completed with underdress, tight hoses, over ankle shoes, crown and a few other details. Our graphical representation of these attires is introduced on the illustration no. 12 and no.13.

The only preserved image of the duchess Elizabeth is her tombstone. Closer look at it brings us many interesting conclusions. The most significant one is that duchess's clothes were for many years misinterpreted. Her gown was considered to be a surcot (dress without sleeves, deeply cut under armholes), whilst it occurs to be underdress covered with tails of a garment resembling modern coat, with elbow length sleeves and without fastening. Schematic drawing no. 21 shows our interpretation of duchess's attire. However, the data are not sufficient to create a reliable reconstruction of her apparel.

We are hoping that our obsevation will help to stress the importance of comparative. 


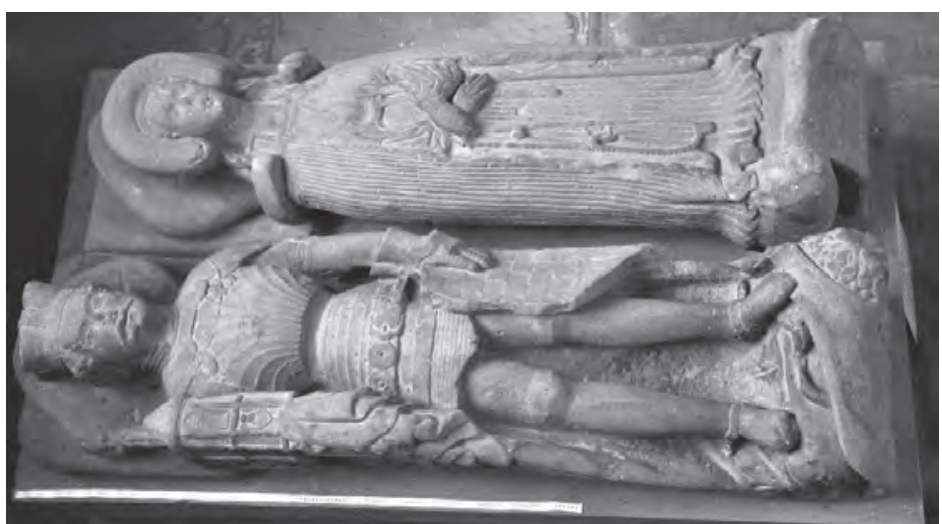

Ryc. 1. Nagrobek pary książęcej, Ludwika II i Elżbiety z Hohenzollernów, Legnica, katedra św. Apostołów Piotra i Pawła (Fot. K. Badowska)

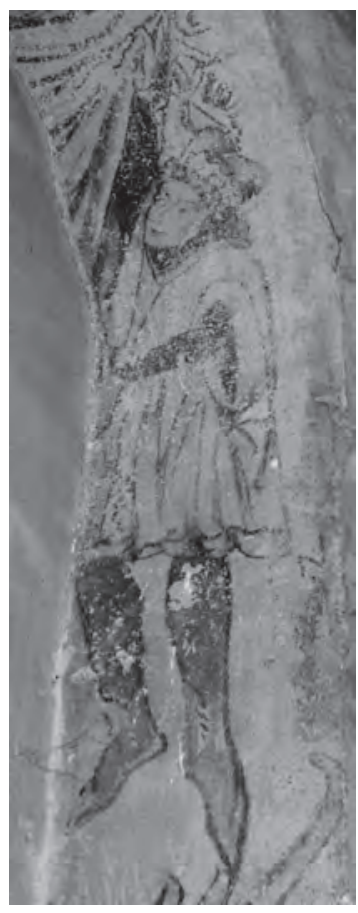

Ryc. 2. Ludwik II legnicko-brzeski, zakrystia kościoła św. Mikołaja w Brzegu (Fot. W. Wasiak)

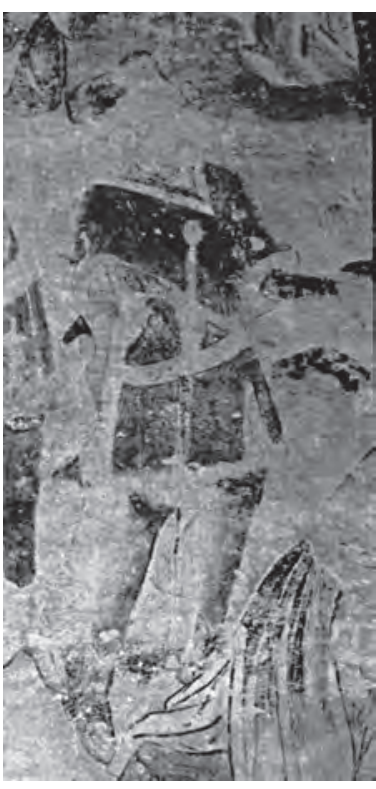

Ryc. 3. Ludwik II legnicko-brzeski w scenie Hołdu Trzech Króli, kościół Wniebowzięcia NMP w Krzyżowicach (Źródło: dok., fot.: Ośrodek Konserwacji Zabytków O/Warszawa, Pracownia Dokumentacji Naukowo-Historycznej. Obecnie Ośrodek Konserwacji Zabytków w Opolu) 


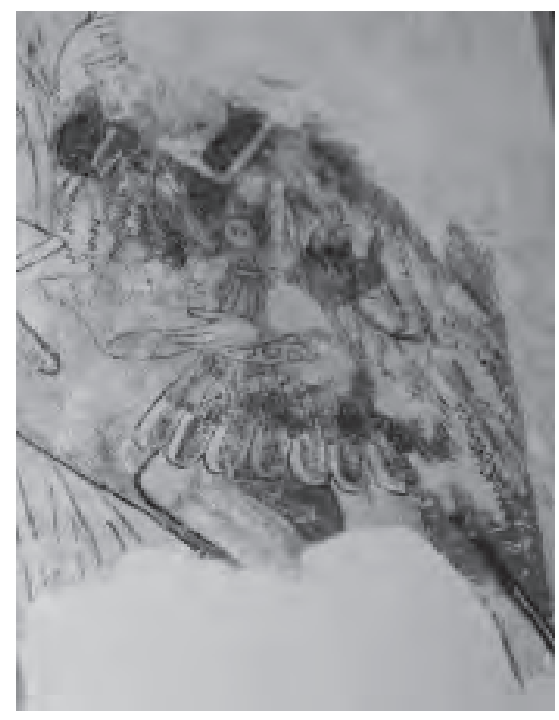

Ryc. 4. Ludwik II legnicko-brzeski, scena Hołdu Trzech Króli, kościół św. Andrzeja w Strzenikach (Źródło: dokumentacja konserwatorska, 2005 r., fot. 003, Wojewódzki Ośrodek Ochrony Zabytków w Opolu)

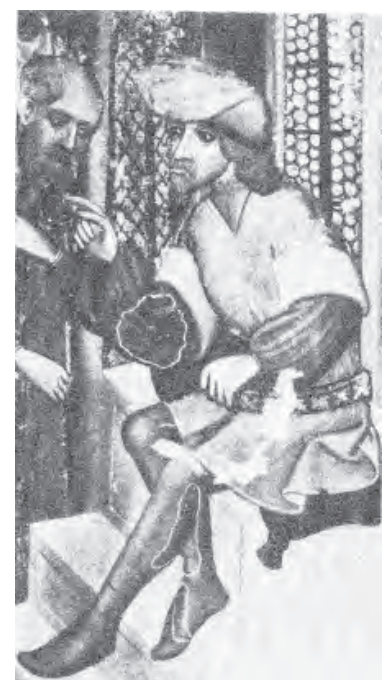

Ryc. 6. Piłat,

Ołtarz z Ptaszkowej, ok. 1440 r. (Źródło: Tarnów, Muzeum Diecezjalne, fot. J. Langda)

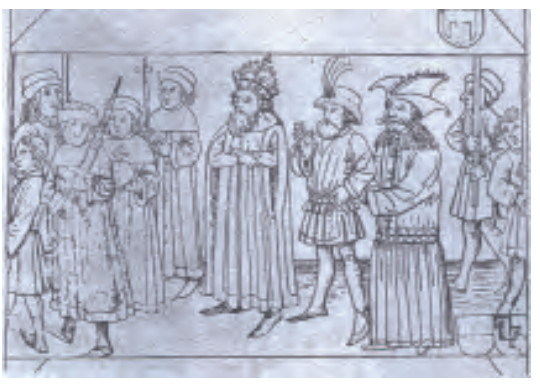

Ryc. 5A) Zygmunt Luksemburski w procesji Bożego Ciała w 1417 r. (Źródło: Szafrański 1972: il. 8)

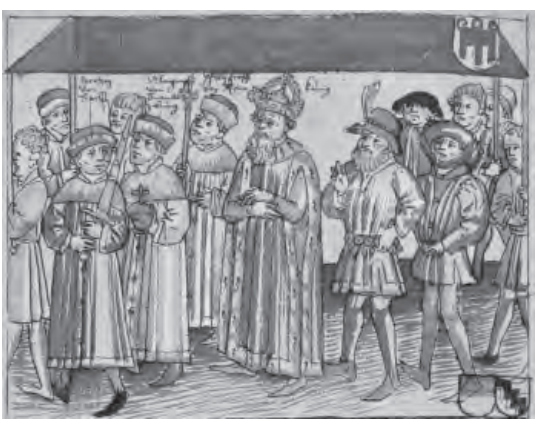

Ryc. 5B) Zygmunt Luksemburski w procesji Bożego Ciała w $1417 \mathrm{r}$. (Źródło: Chronik des...)

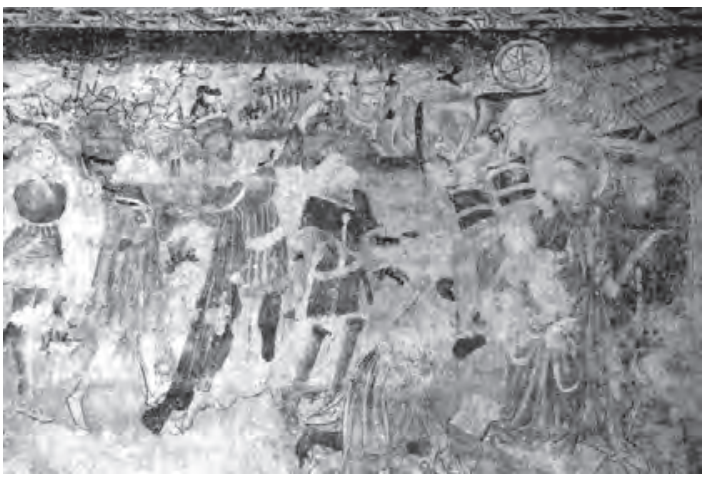

Ryc. 7. Ludwik II legnicko-brzeski w scenie Hołdu Trzech Króli, kościół Wniebowzięcia NMP w Krzyżowicach (Fot. R. Baran) 


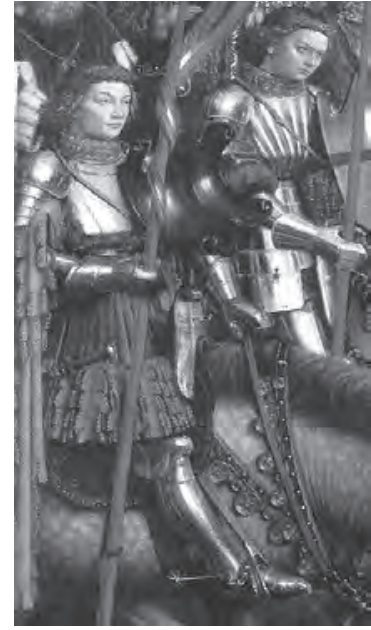

Ryc. 8. Rycerze Chrystusa z ołtarza gandawskiego z ok. 1432 roku Jana van Eycka (Źródło: Limertani Virdis, Pietrogiovanna 2004: 62)

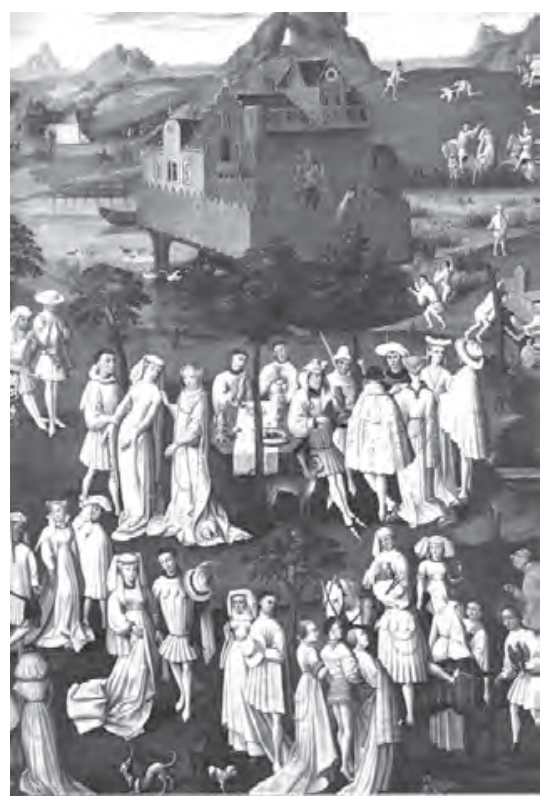

Ryc. 10. Polowanie z sokołem na dworze Filipa Dobrego, II ćw. XV w., Wersal, Musée National du Château (Źródło: Boucher 2009: 169)

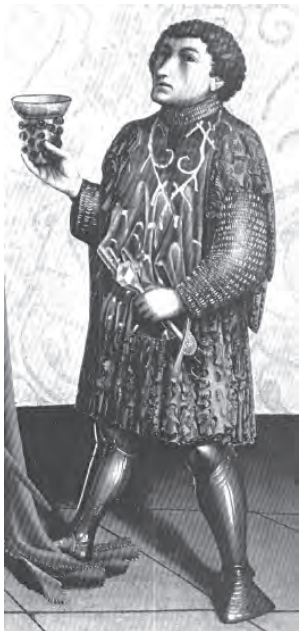

Ryc. 9. Benajasz, Abiszaj, Subotaj i Benajasz przed Dawidem, tablice Ołtarza Zwierciadła Zbawienia, Konrad Witz,ok. 1435

(Źródło: Krüger 1974, sekcja 9)

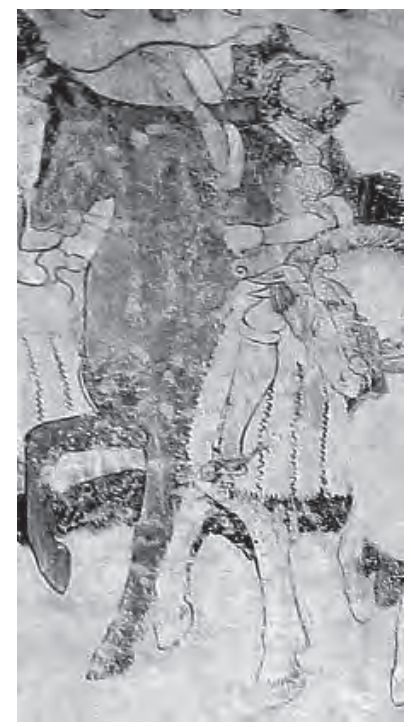

Ryc. 11. Scena Hołdu Trzech Króli, kościół św. Andrzeja w Strzenikach (Źródło: dokumentacja konserwatorska, z 2005 r., fot. 2008, Wojewódzki

Ośrodek Ochrony Zabytków w Opolu) 


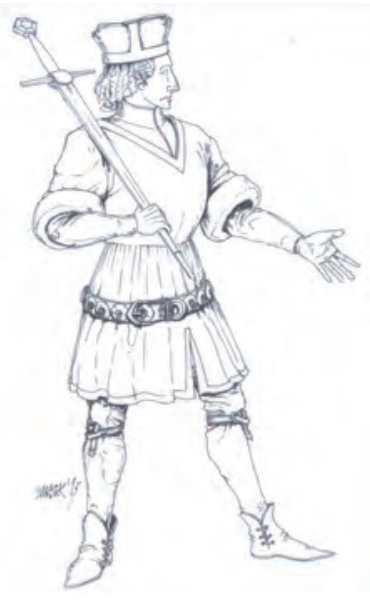

Ryc. 12. Próba rekonstrukcji stroju Ludwika II legnicko-brzeskiego. Strój wg przedstawienia księcia z kościoła w Krzyżowicach (Oprac. W. Wasiak, K. Badowska; rys. W. Wasiak)

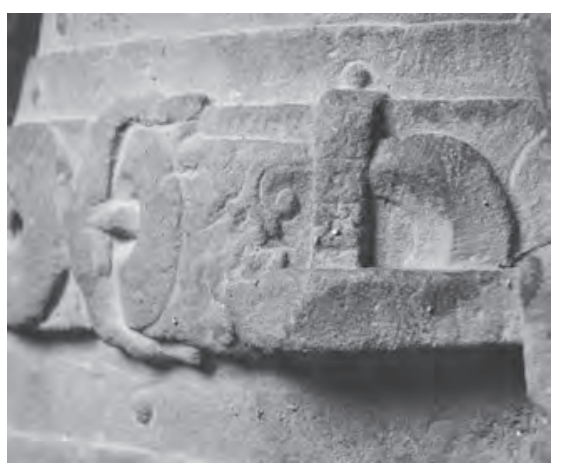

Ryc. 14. Pas rycerski Ludwika II legnicko-brzeskiego, nagrobek księcia, katedra św. Apostołów Piotra i Pawła w Legnicy (Fot. W. Wasiak)

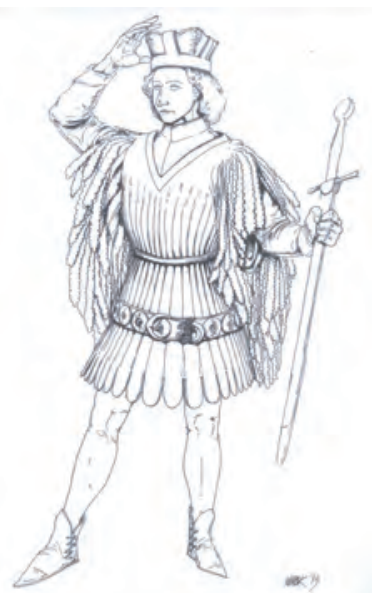

Ryc. 13. Próba rekonstrukcji stroju Ludwika II legnicko-brzeskiego. Strój wg przedstawienia księcia z kościoła w Strzelnikach (Oprac. W. Wasiak, K. Badowska; rys.W. Wasiak)

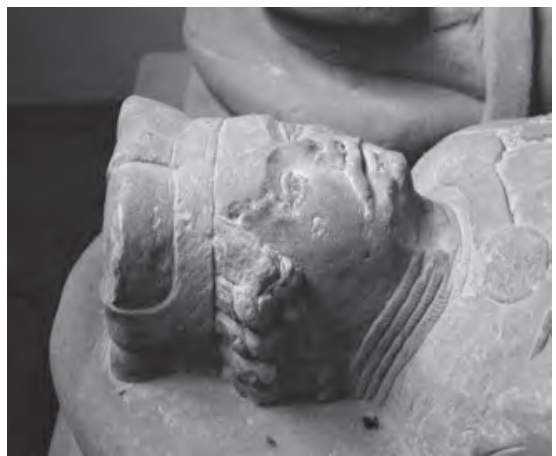

Ryc. 15. Popiersie Ludwika II legnicko-brzeskiego, nagrobek księcia, katedra św. Apostołów Piotra i Pawła w Legnicy (Fot. W. Wasiak)

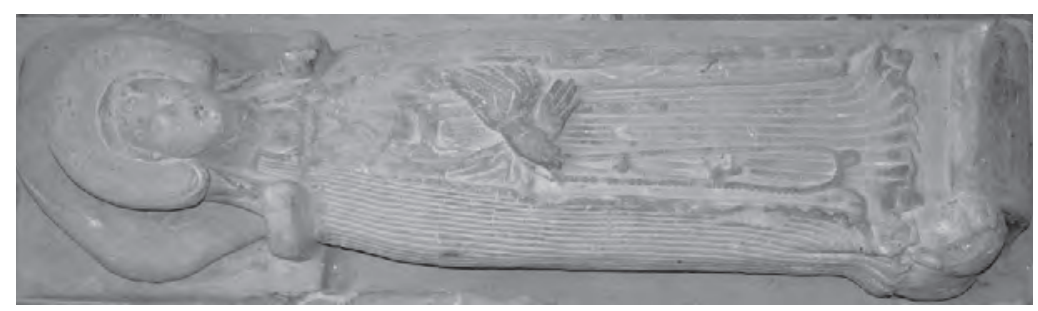

Ryc. 16. Nagrobek księżnej Elżbiety z Hohenzollernów, katedra św. Apostołów Piotra i Pawła w Legnicy

(Fot. W. Wasiak) 


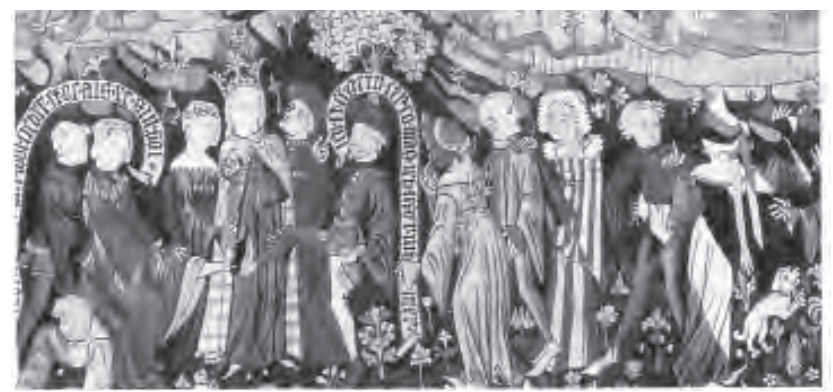

Ryc. 17. Gry i zabawy z niemieckiej tapiserii z XV wieku, Real Biblioteca de San Lorenzo de El Escorial, PG 22 (Źródło: Bartlett 2002: 127)
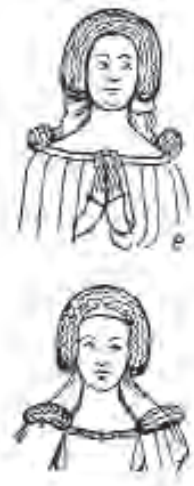

Ryc. 18. Przykłady kruselera z XIV wieku

(Źródło: Gutkowska-Rychlewska 1968: 163, il. 193)

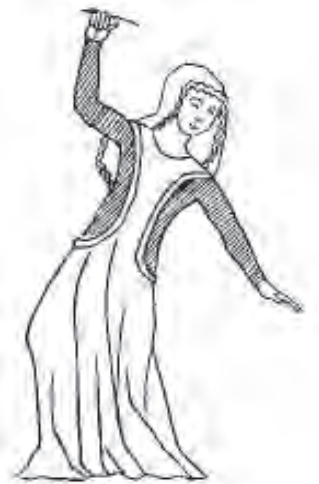

Ryc. 19. Suknia typu surcot noszona razem z kruselerem z poł. XIV w. (Źródło: Gutkowska-Rychlewska 1968: 145, il. 166)

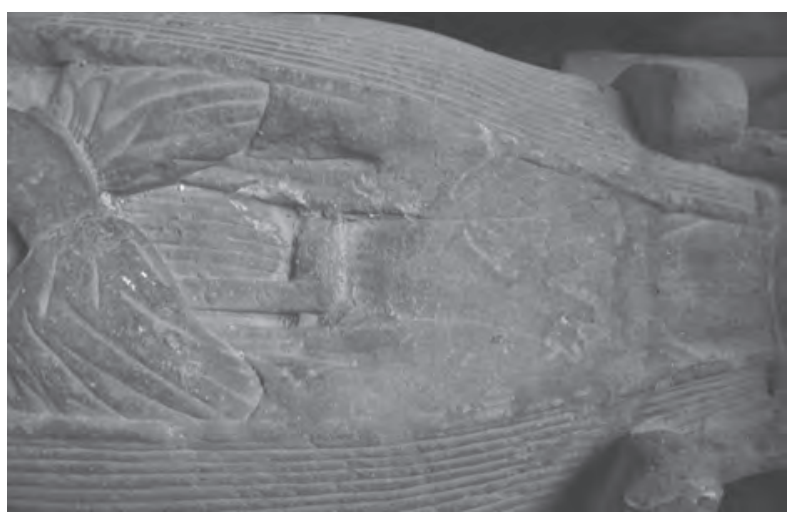

Ryc. 20. Zbliżenie ułożenia kolejnych warstw garderoby księżnej Elżbiety, katedra św. Apostołów Piotra i Pawła w Legnicy (Fot. K. Badowska) 


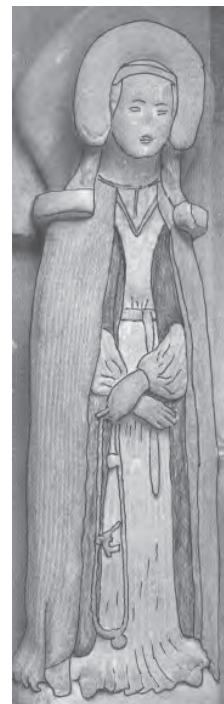

Ryc. 21. Obrys części garderoby, nagrobek księżnej Elżbiety, katedra św. Apostołów Piotra i Pawła w Legnicy, (Fot. i oprac. K. Badowska)

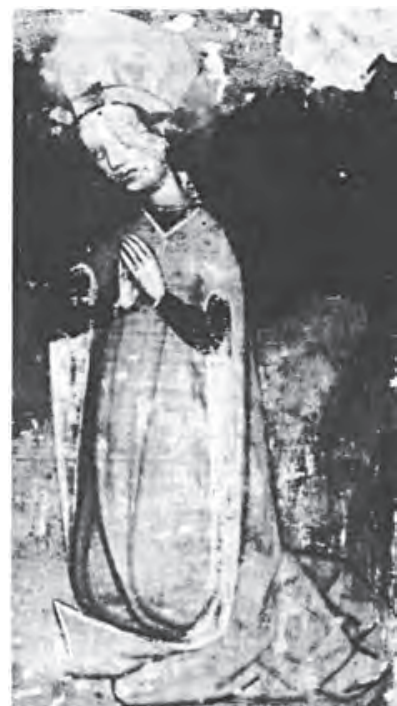

Ryc. 22. Polska suknia wzorowana na houppelande, postać z ołtarza z Nowego Sacza, ok. 1452 (Źródło: Tarnów Muzeum Diecezjalne, IS, neg. Nr 64981; Turska 1987: 158, il. 96b)

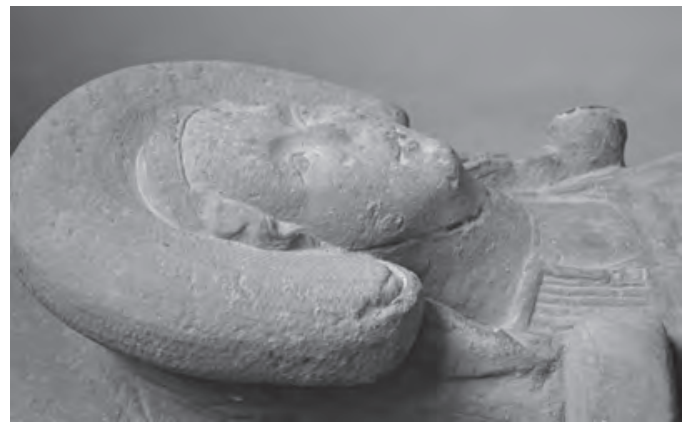

Ryc. 23. Czepiec, nagrobek księżnej Elżbiety, katedra św. Apostołów Piotra i Pawła w Legnicy, (Fot. K. Badowska)

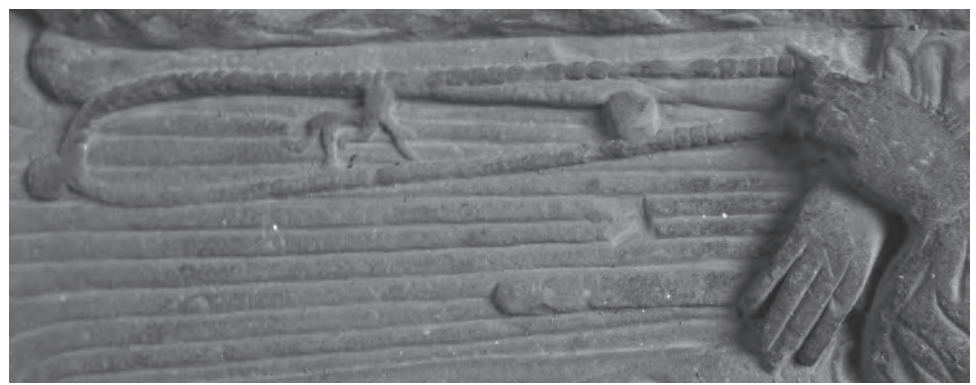

Ryc. 24. Paternoster widoczny w dłoni księżnej Elżbiety, nagrobek w katedrze św. Apostołów Piotra i Pawła w Legnicy

(Fot. K. Badowska) 